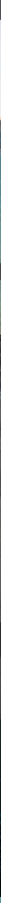

EMERALD STUDIES IN FINANCE, INSURANCE, AND RISK MANAGEMENT

VOLUME 3

\title{
INSURANCE AND RISK
}

MANAGEMENT FOR DISRUPTIONS

IN SOCIAL, ECONOMIC AND

ENVIRONMENTAL SYSTEMS

DECISION AND CONTROL ALLOCATIONS

WITHIN NEW DOMAINS OF RISK

SIMON GRIMA • ERCAN ÖZEN

REBECCA EMILY DALLI GONZI 


\section{Insurance and Risk Management for Disruptions in Social, Economic and Environmental Systems}




\title{
EMERALD STUDIES IN FINANCE, INSURANCE, AND RISK MANAGEMENT
}

\author{
Series editors: Ercan Özen and Simon Grima
}

Books in this series collect quantitative and qualitative studies in areas relating to finance, insurance, and risk management. Subjects of interest may include banking, accounting, auditing, compliance, sustainability, behavior, management and business economics.

In the disruption of political upheaval, new technologies, climate change and new regulations, it is more important than ever to understand risk in the financial industry. Providing high quality academic research, this book series provides a platform for authors to explore, analyzes and discuss current and new financial models and theories, and engage with innovative research on an international scale.

\section{Previously published:}

Uncertainty and Challenges in Contemporary Economic Behaviour, Ercan Özen and Simon Grima

New Challenges for Future Sustainability and Wellbeing, Ercan Özen, Simon Grima and Rebecca Dalli Gonzi 


\section{Insurance and Risk Management for Disruptions in Social, Economic and Environmental Systems: Decision and Control Allocations within New Domains of Risk}

EDITED BY

SIMON GRIMA

University of Malta, Malta

ERCAN ÖZEN

University of Uşak, Turkey

$\&$

REBECCA EMILY DALLI GONZI

University of Malta, Malta
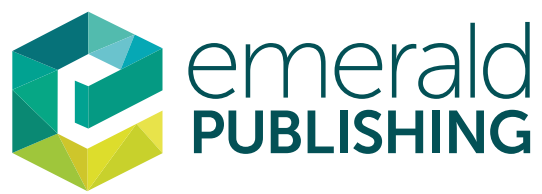

United Kingdom - North America - Japan - India - Malaysia - China 
Emerald Publishing Limited

Howard House, Wagon Lane, Bingley BD16 1WA, UK

First edition 2022

Editorial matter and selection (C) 2022 Simon Grima, Ercan Özen and Rebecca Emily Dalli Gonzi. Published under exclusive licence by Emerald Publishing Limited.

Individual chapters (C) 2022 Emerald Publishing Limited.

\section{Reprints and permissions service}

Contact: permissions@emeraldinsight.com

No part of this book may be reproduced, stored in a retrieval system, transmitted in any form or by any means electronic, mechanical, photocopying, recording or otherwise without either the prior written permission of the publisher or a licence permitting restricted copying issued in the UK by The Copyright Licensing Agency and in the USA by The Copyright Clearance Center. Any opinions expressed in the chapters are those of the authors. Whilst Emerald makes every effort to ensure the quality and accuracy of its content, Emerald makes no representation implied or otherwise, as to the chapters' suitability and application and disclaims any warranties, express or implied, to their use.

\section{British Library Cataloguing in Publication Data}

A catalogue record for this book is available from the British Library

ISBN: 978-1-80117-140-3 (Print)

ISBN: 978-1-80117-139-7 (Online)

ISBN: 978-1-80117-141-0 (Epub) 


\section{Contents}

About the Editors vii

About the Contributors ix

Foreword xix

Chapter 1 Mapping Out Cross-sectoral Collaboration and Multi-level Governance Within Single Use Plastic Policy:

An Analysis

Clinton Cassar and Mario Thomas Vassallo

Chapter 2 Financial Regulation and Bank Supervision During a Pandemic

Peterson K. Ozili

Chapter 3 A Study of Insurance Contracts Within the Legal Context of a Small Island Influenced by the Commonwealth, the European Union and the Mediterranean: The Case of Utmost Good Faith and Insurable Interest

Ramon Mizzi, Andre Farrugia and Simon Grima

Chapter 4 Consumer Behavior in the New Economic Reality. Approaches to Personalized Medicine: From Paradigms to Challenges

Artiom Jucov, Liliana Staver and Larisa Mistrean

Chapter 5 Determination of the Sensitivity of Stock Index to Macroeconomic and Psychological Factors by MARS Method Münevvere Ylldiz and Letife Özdemir 
Chapter 6 Enterprise Risk Management Assessment of Romanian Listed Companies for Sustainable Development Camelia-Daniela Hategan, Nicoleta Sirghi and Ruxandra Pitorac

Chapter 7 The Effects of Capital Structure Decisions on Financial Risk and Failure: A Research on BIST Food Companies Serdar Yaman and Turhan Korkmaz

Chapter 8 Global Impasses in Public Services Provision Due to Covid-19 in G20 Countries

Sevilay Ece Gümüş Özuyar

Chapter 9 Implementation of Sustainability

Özlem Tuna

Chapter 10 Sustainability Risk Management: A Survey of the Literature

Oya Korkmaz

Chapter 11 Financial Institutions' Governance Innovation and Credibility Strategy

Tjaša Štrukelj, Sabina Taškar Beloglavec, Daniel Zdolšek

and Vita Jagrič

Chapter 12 CSR 4.0 Dimensions in Relation to the Advantages of Industry 4.0

Anca Băndoi, Cătălina Sitnikov, Anca Tănasie and Ionut Riza

Chapter 13 European Insurance Market Development under the Economic Welfare: Advanced Econometric Approaches Mirela Cristea, Grațiela Georgiana Noja, Silviu-Valentin Cârstina, and Elena Sorina Caragiani 


\section{About the Editors}

Simon Grima, PhD (Melit.), MSc (Lond), MSc (BCU), BCom (Hons) (Melit.), FFA, FAIA (Acad), is the Head of the Department of Insurance, in charge of the Bachelor of Commerce in Insurance, the Bachelor of Commerce (Honours) and Master's degrees in Insurance and Risk Management and an Associate Professor at the University of Malta. He set up the Insurance Department in 2015 and started and coordinates the MA and MSc Insurance and Risk Management degrees. He served as the President of the Malta Association of Risk Management (MARM) between 2013 and 2015, and President of the Malta Association of Compliance Officers (MACO) between 2016 and 2018. Moreover, he is among the first Certified Risk Management Professional (FERMA), is the Chairman of the Scientific Education Committee of the Public Risk Management Organization (PRIMO) and a member of the curriculum development team of Professional Risk Managers' International Association (PRMIA) in 2014. His research focus and consultancy is on Governance, Regulations and Internal Controls (i.e., risk management, internal audit and compliance) and has over 30 years of experience varied between financial services and with public entities in academia, internal controls, investments and IT. He acts as an Independent Director for Financial Services Firms, sits on Risk, Compliance, Procurement, Investment and Audit Committees and carries out duties as a Compliance Officer, Internal Auditor and Risk Manager.

He has acted as Co-chair and is a Member of the scientific program committee on some international conferences and is a Chief Editor, Editor and Review Editor of some Journals and Book Series. He has been awarded outstanding reviewer for Journal of Financial Regulation and Compliance in the 2017 Emerald Literati Awards.

Dr Ercan Özen, received his BSc in Public Finance (1994), MSc in BusinessAccounting (1997), PhD in Business Finance (2008) from University of Afyon Kocatepe. Now he is Associate Professor of Finance in Department of Banking and Finance, School of Applied Sciences, "University of Uşak, Turkey." His current research interests include different aspects of Finance. He has (co-) authored five book chapters and more than 40 papers, more than 30 conferences participation, member in International Program Committee of three conferences and workshops. He is Chair of International Applied Social Sciences Congress. $\mathrm{He}$ is also the Certificated Accountant, Member of Agean Finance Association and member of Turkey Combating Soil Erosion, for Reforestation and the Protection of Natural Resources Foundation (TEMA). 
Rebecca Emily Dalli Gonzi, PhD (Glasg), MSc (Edin), BE \& A., (Melit) (Hons), A. \& C.E., A.L.C.M. (Lond), is an Architect, Project Coordinator and Lecturer. She is a Registered and Certified Civil Engineer by the Chamber of Architects Malta, and a Registered Chartered Member of the Royal Institute for British Architects London. She has worked in the private and public sector, both in Malta and in Scotland. She is a Resident Academic at the University of Malta lecturing project management in the Department of Construction and Property Management and within the Department of Insurance, in Geopolitical and Environmental Risk, and Business continuity Management. She lectures Project Development at the Institute for Sustainable Energy. She founded the DALI Model, which is a tool for assessing organizational risk, which can be used when firms require a recovery response due to a crisis. This model has been presented as an empirically tested model in a specific setting for managing organizational risk so that firms achieve their goals with minimal setbacks. Her book entitled Change and Continuity Management in the Public Sector, which presents the research underlying this model, reinforces the idea that good governance requires the right decisiontaking methods if any organization is to succeed. Areas in her portfolio of research include organizational management, strategic project management and construction management. 


\title{
About the Contributors
}

\begin{abstract}
Anca Băndoi, currently Dean of Faculty of Economics and Business Administration, University of Craiova, is PhD Associate Professor at the Faculty of Economics and Business Administration. She holds a Doctorate in Cybernetics and Economic Statistics since 2002 and a postdoctoral degree in the field of Financial Modeling from the European Structural Funds through the University of Craiova since 2014. She has been teaching Undergraduate and Master students since 1995. Her main research areas include Macroeconomics, Microeconomics, Financial Modeling, Financial Analysis, Financial Forecasting and Evaluation of Real Estate Properties. Her research has resulted in the publication of four books as a single author and co-author and more than 30 articles in important specialized journals. In the last 11 years, she was part of the management team of the University of Craiova in charge of Education Quality Assurance.
\end{abstract}

Mag. Sabina Taškar Beloglavec is a Senior Lecturer in the field of Finance at the Faculty of Economics and Business of the University of Maribor, Slovenia, Department for Finance and a Researcher at the Institute for Finance and Artificial Intelligence. She concluded her graduate and postgraduate studies at the University of Maribor. Her main research interests are post-Covid-19 bank digitalization and business model change, ethical and socially responsible banks' activities, non-financial reporting in financial institutions and international taxation. She has published several articles in national and international journals, parts of monographs and has attended several international scientific conferences. She is also active in other fields, for example, a Member of Union Supervisory Board, Educates Primary School Pupils on financial knowledge and was a Member of Curriculum Development Group and Supervision of Secondary Schools at the National Education Institute of the Republic of Slovenia.

Elena Sorina Caragiani is a PhD Student at the Doctoral School of Economic Sciences, field of Economics, University of Craiova. She graduated the Faculty of Economics and Business Administration and the Faculty of Law (bachelor degrees), and she has a master degree in the Management of Human Resources. At present, she works at the General Directorate of Social Assistance from Craiova, as Head of Office, for the Service of Strategies, Programs and Projects in the field of social assistance and the relationship with the associations and foundations. She is also an Affiliate Member of the Center for Economic, Banking and Financial Research (CEBAFI) within the University of Craiova, 
and a Member of several European-funded projects implemented at the level of the institution. Her main research directions are social inclusion, poverty and sustainable development.

Silviu-Valentin Cârstina is a Lecturer at the University of Craiova (Romania), Faculty of Economics and Business Administration, Department of Finance, Banking and Economic Analysis. He obtained the scientific title of $\mathrm{PhD}$ in Finance in 2015. He is the Author of numerous research papers on: risk analysis of economic entities, analysis of economic and financial performance, evaluation of assets, asset management, as well as topics of macroeconomic nature, focused on the insurance market and the labor market. During his career, he deployed mobility internships in Spain, at the University of Rioja, and in Croatia, at the University of Croatia (Zagreb), which resulted in numerous research published papers. He was included as Team Member in several projects with European funding, having as responsibilities the elaboration of cost-benefit analysis, impact analysis and budget execution.

Clinton Cassar is a Visiting Lecturer at the Department of Public Policy, University of Malta. In 2008, he was awarded a Bachelor of Arts (Hons) degree in Geography with first-class honors, followed by a Postgraduate Certificate in Education a year after. In 2015, he was awarded a Master in Education for Sustainable Development with distinction. He has published original research in the areas pertaining to governance, education and sustainability both in local and international journals. Throughout the years, he also provided his expertise as a Trainer and Consultant with various private and public entities.

Mirela Cristea is a Professor at the University of Craiova (Romania), Faculty of Economics and Business Administration, Department of Finance, Banking and Economic Analysis, Center for Economic, Banking and Financial Research (CEBAFI). Her main research directions and teaching activities are insurance and private pension funds, banking administration, interdisciplinary research in economics. She obtained the scientific title of $\mathrm{PhD}$ in Economics at the University of Craiova, and graduated the Postdoctoral School in Economics and Applied Sciences in Economics at the Romanian Academy from Bucharest, on the subject of private pension system in Romania. She received two awards from the Faculties on Economics Association from Romania, in 2007 and 2013, for two books on life insurance and pension system subjects. In addition, she is a Reviewer and Member of the scientific and organizational committees for numerous journals and conferences.

Andre Farrugia commenced his professional career working in the insurance industry before moving to training during which he occupied the post of Director of Studies. He is currently part of the academic staff within the Insurance Department at the University of Malta. He has achieved the Fellowship of the Chartered Insurance Institute (FCII-UK) and the Fellowship of the Institute of Risk Management (CFIRM-UK). He has completed an MSc in Risk Management with the Glasgow-based University of Caledonian and is currently 
reading for a $\mathrm{PhD}$ with the University of Malta. During his professional career, he has contributed to the industry through the publication of articles and papers and has delivered various lectures in renowned Universities in Latvia, Serbia and Kosovo. He also sat on a number of insurance boards and industry associations.

Simon Grima, is an Associate Professor, heading the Department of Insurance, within the Faculty of Economics, Management and Accountancy at the University of Malta. He is a Visiting Professor at UNICATT Milan and the University of Latvia. Moreover, he served as the President of the Malta Association of Risk Management, the Malta Association of Compliance Officers, is a Board Member of the Federation of European Risk Managers and the Public Risk Management Association. His research focus and consultancy is on Governance, Finance, Risk Management and Internal Controls and has over 25 years of experience in various private and public entities.

Camelia-Daniela Hategan is a Professor PhD habil. of Accounting, at Faculty of Economics and Business Administration, West University of Timisoara, Accounting and Auditing Department. The author's areas of interest in research include financial accounting, international financial reporting standards, financial audit and entrepreneurship in the accounting profession and corporate social responsibility. She is a member of professional accounting association, the Chamber of Financial Auditors of Romania (CAFR), being IFAC member. She published and presented numerous papers in this field in scientific journals indexed in Web of Science or other relevant databases and conference proceedings. She has reviewed many articles for relevant journals, for example, Sage Open, Economic Research, Sustainability, Education, International Journal of Financial Studies, and conferences, for example, International Business Information Management Association (IBIMA).

Dr. Vita Jagrič is an Assistant Professor of Finance at University of Maribor, Slovenia, Faculty of Economics and Business (EPF), Department for Finance and a Researcher and Consultant at the Institute for Finance and Artificial Intelligence. Her background is in economics and law. Her $\mathrm{PhD}$ thesis was exploring banks' quantitative risk management methods in credit risk. She was a Speaker at European convention in quantitative methods and risk management at University of Hull (UK), and at European Actuarial Academy's Seminar: Capturing Risks in Insurance Premiums. Her research interest comprises risk management and insurance, public finance and taxation, financial regulation and supervision. She has published several articles as (co)author in (inter)national journals and monographic units. Recently, her research also includes health policy and health economics, exploring the economic impact and architecture of the healthcare sector on national, regional and local level.

Assoc. Prof Dr Artiom Jucov has a PhD in Social Medicine and Management, MA in Policy and Public Services and is a Member of the Family Medicine Department of the USMF "Nicolae Testemitanu" and Assis. Prof at the 
University of Physical Education and Sports from Moldova. Since 2015 he has served at the National Anti-doping Agency of Moldova as Anti-doping Officer and in the period of 2019-2020 as Director of the Agency. Since 2020 he is the Project Director and Principal Investigator of the Moldovan state research program "Phenomenon of youth doping from the medical and bioethical aspect" (2020-2023). However, he is the postdoctoral student in project "Streamline of the management of personalized medicine based on the behavioral study of patients" within the Academy of Economic Studies of Moldova. He is the Author of 46 scientific papers in the field of Social Medicine, Personalized Medicine, Management, Family Medicine and Antidoping.

Oya Korkmaz received her $\mathrm{PhD}$ degree in 2011 upon completing the doctoral study program of the Business Administration Department of Zonguldak Bülent Ecevit University Graduate School of Social Sciences in Turkey. She worked as an Assistant Professor at Zonguldak Bulent Ecevit University Vocational School between 2011 and 2013, and at Tarsus University School of Applied Technology and Management between 2013 and 2017 in Turkey. She became an Associate Professor in the field of Management and Strategy Science in 2017. The scope of her research covers the fields of organizational behavior, human resources and strategic management. She has published several articles in peer-reviewed journals, presented papers in international conferences and served as a referee in international journals in her field.

Turhan Korkmaz is a Professor of Finance at Mersin University, Turkey. He also served 14 years as a Faculty Member at Zonguldak Bulent Ecevit University, Turkey. He is the Author and Co-author of nine books, 16 edited volumes, over 90 research articles in leading journals, and presented dozens of papers in the field of finance at national and international conferences. He has made several important research contributions in corporate finance, capital markets, portfolio management, international asset allocation and risk management. $\mathrm{He}$ has completed his first degree in business administration at Bursa Uludag University, Turkey and he also holds MBA and PhD degrees in finance from Chicago Illinois Institute of Technology, USA.

Larisa Mistrean has more than 28 years of scientific-didactic and research experience in the area of economics. She is an Associate Professor at the Academy of Economic Studies of Moldova, Investments and Banking Activity Department. Her research focuses in the area of banking management and marketing, corporate governance, monetary policy has more than 70 papers.

She is the Project Director and Principal Investigator of the Moldovan state research project "Behavioral evolutions of consumers of financial-banking services in the new economic configuration" (2021-2024).

She is a MC Member in COST ACTION 19103 - LGBTI + Social and Economic (in)equalities and MC Substitute in COST ACTION 17125 - Public Value Capture of Increasing Property Values; an Editorial Member and Member of committee of Reviewers of the International and National Journals of Finance 
and Banking Research; Member of Scientific Committee; and Member of Organizing Committee of the International Scientific Conferences organized in Moldova, Turkey and Romania.

Ramon Mizzi started his insurance career in 1985 and was elected Associate of the Chartered Insurance Institute in 1989. In 1992 he graduated as Bachelor of Arts (Socio-Legal Studies) at the University of Malta. He has a particular interest in the legal aspect of the insurance profession. He recently completed his Masters in Insurance \& Risk Management at the University of Malta. He has been involved in practically all classes of insurance business in Malta and has held various senior executive positions within the Maltese Insurance. He is a Visiting Lecturer at the Department of Insurance at the University of Malta.

Grațiela Georgiana Noja is an Associate Professor at the West University of Timisoara (Romania), Faculty of Economics and Business Administration, Department of Marketing and International Economic Relations. She completed her studies at the West University of Timisoara, $\mathrm{PhD}$ habilitation and $\mathrm{PhD}$ in Economics, Master in Management and European integration, BA in International Economic Relations. In addition, she developed several national and international projects has a wide membership in various educational organizations, research networks, scientific and review committees of top tier journals and international conferences. Her main research and teaching activities are developed within the framework of Economics and International Business area, with a focus on world economy, globalization and European economic integration.

Letife Özdemir is an Associate Professor of Finance in Department of Logistics Management, School of Applied Sciences, "University of Afyon Kocatepe," Turkey. She received her BSc in Business (2002), MSc in Business (2005), PhD in Business Finance (2011) from University of Afyon Kocatepe. Her current research interests include different aspects of finance. She has authored three book chapters, 19 papers and 15 conferences participation. She has been involved in two scientific projects and has awarded third prize in the 21st Finance Symposium. She is a Member of Turkey Combating Soil Erosion, for Reforestation and the Protection of Natural Resources Foundation).

Peterson K. Ozili is an Economist, affiliated with the Central Bank of Nigeria. His works are extensively in Academia and Policy-making. He has experience in economic policy, financial inclusion, financial stability, financial innovation, banking regulation and supervision.

His areas of specialization are: financial economics, international development, accounting, development finance, the economics of financial markets, banking and financial reporting.

He has published extensively in many accounting and finance journals such as the British Accounting Review, Journal of Applied Accounting Research, Journal of Accounting in Emerging Economies, International Journal of Managerial 
Finance, European Journal of Finance, Research in International Business and Finance, etc.

Sevilay Ece Gümüş Özuyar is an Assistant Professor of Public Finance working as a Full-time Member of Staff in Public Finance Department at Necmettin Erbakan University. She earned two bachelor degrees in Economics and International Relations at Gazi University, MA Degree in Finance at Drexel University and $\mathrm{PhD}$ degree in Public Finance at Hacettepe University. Her research interests include public policy, public economics, public goods, economic security and terrorism. She has two books, "Welfare Economics, Public Goods and Life Satisfaction: A New Perspective" and "On Terror and Terrorism: An Evaluation of Causes and Results Specific to PKK," and several book chapters, articles and editorial books on public economics. She formerly served as a Vice-coordinator of the International Office at Usak University. She is currently an Editor of the Journal of Necmettin Erbakan University Faculty of Politics and an Editorial Board Member of Journal of Sosyoekonomi indexed in e-SCI.

Ruxandra Pitorac is a Lecturer in the Department of Economics and Economic Modeling, at the Faculty of Economics and Business Administration, West University of Timisoara, Romania, where she teaches in the area of microeconomics, macroeconomics and European integration. She is a Member of the Editorial Board of Timisoara Journal of Economics and Business (TJEB) and Reviewer for many international journals and conferences. She is the Author of several articles in academic journals and received two awards for research results given by the Ministry of National Education. Also, she was in the organizing committee of several national and international conferences and participated in grants, as a Member or as a Director. Her current research interests are at the microeconomic level on financial performance-sustainability relationship and at the macroeconomic level on sustainable development, labor market and international migration.

Ionuț Riza obtanined their bachelor degree in Economics, specializing in Business Informatics (2007), with a master degree in Business Administration (2009). Since 2019 he completed his PhD in Management. He is currently pursuing the postdoctoral studies program at the University of Craiova. The main objective of the postdoctoral research project is to analyze the management of human resources skills from the perspective of risk management at organizational and cyber level. The research is based on assessing the skills needed by employees whose activities influence the security of any organization. This includes both the regular employee, who uses the internet or computer network of the organization, and IT security professionals. Another objective is to implement the proposed model of cybersecurity skills based on minimum general knowledge, skills and abilities in the field of computers, software, information and communications, so that any employee masters the essential requirements to successfully perform tasks. During the study program he has written several scientific papers presented at international conferences, some of which were published in professional journals. Since 2007, he had been working 
as Marketing Manager for a consulting firm in Occupational Safety and Health. $\mathrm{He}$ is a Risk Assessor and an Auditor in Occupational Safety and Health, as well as a Professional Qualification Trainer.

Nicoleta Sirghi is a Professor PhD habil. of Economics at the Faculty of Economics and Business Administration, West University of Timisoara, Romania. The current research field is related to study the oligopolistic market and the game theory with applications in economics. She has published in the International Journal of Bifurcation and Chaos (IJBC), Sustainability, Transformations in Business and Economics (TBE), Journal of Economic Computation and Economic Cybernetics Studies and Research (ECECSR), etc. Recent publications include articles on corporate social responsibility. She is a Member of the Editorial Board of Timisoara Journal of Economics and Business (TJEB) and Reviewer for many international journals and conferences: Sustainability, British Journal of Economics, Management \& Trade, British Journal of Mathematics \& Computer Science and IBIMA Conferences. She is a Member of professional economics associations: Regional Science Association International (RSAI), Association Internationale des Economistes de Langue Française (AIELF) and Reseau Pays du Groupe de Vysegrad (PGV).

Cătălina Sitnikov is a PhD Professor at the University of Craiova in Romania, at the Faculty of Economics and Business Administration. She holds a doctorate in Management since 2000, Habilitation title in Management since 2014 and since February 2015 she has been a PhD supervisor in Management. She was for three years a Visiting Lecturer at Helsinki University of Technology, Lahti Center in Finland. Since 1995, she has been teaching undergraduate, master and $\mathrm{PhD}$ students. She teaches Quality Management, Total Quality Management and Management. Her main research areas include management, strategic management, and mostly quality management, instruments and models specific to the stages of quality planning, control and improvement, quality management strategies, ISO standards, CSR from the perspective of specific standards and instruments.

Liliana Staver is a $\mathrm{PhD}$ candidate in Marketing and Logistics. Her main research fields of interest are: international business, logistics and supply chain management, inter-, trans- and multidisciplinary research and neuromarketing. She is a Chief Editor of the International Journal "Working Papers" indexed in three international databases (CEEOL, DOAJ and RePEc). She has presented various papers at international conferences and she has published more than 30 articles and papers in national and international journals.

She is a MC Member in COST ACTION 18214 - The Geography of New Working Spaces and the Impact on the Periphery; and MC Substitute in COST ACTIONS: 18232 - Mathematical models for interacting dynamics on networks and 18126 - Writing Urban Places. New Narratives of the European City. Moreover, she is a Team Leader Expert in international Erasmus projects, as MINERVA - Strengthening Research Management and Open Science Capacities of HEIS in Moldova and Armenia. 
Dr Tjaša Štrukelj is an Associate Professor of Governance and Strategic Management at the University of Maribor, Faculty of Economics and Business (EPF), Department of Strategic Management and Company Policy, Institute for Corporate Governance and Strategic Management. She is the (Co) author of articles in various (inter) national journals, monographs and conferences (http:// www.cobiss.si/, 16338). She was (2015-2018; 2016-2017 and 2018-2019) and is (2019-2021) a Member of the International Research Team, leads the Faculty part of Erasmus+ project Economic of Sustainability (2019-2022) and bilateral international research project (2019-2021), actively participates in the research program Entrepreneurship for Innovative Society (2016-), is a Member of the Program Committee of the journals Oeconomica Jadertina, Croatia (2017-), Journal of Research and Innovation for Sustainable Society, Romania (2019), Acta Economica, Bosnia and Herzegovina (2020-), is a Certified Leader for Social Responsibility and Sustainable Development (2019-) and Path to Integrity Community Leader for Slovenia (2020-).

Anca Tănasie is an Associate Professor PhD at University of Craiova, Romania the Faculty of Economics and Business Administration and Invited Lecturer at Bifrost University, Iceland. She has held the PhD degree in International Business and Economics since 2007. Main research areas include: European economics, regional development, European monetary integration, sustainable development, education, quality assessment and transversal skills in higher education. She is the Author and Co-author of several scientific papers published in international journals and/or presented at international conferences, books and chapters in books and she is also a Reviewer for international ISI scientific journals.

Özlem Tuna is an Associate Professor of Management and Strategy at Afyon Health Sciences University, Faculty of Health Sciences. She has a doctorate degree in the Business Administration. She formalized in her PhD (2014) on Corporate Sustainability. She has managerial experience in the private sector between 1997 and 2002, she has been working in university since 2002 . Her research focuses on the field of corporate sustainability, other strategic management issues and organizational behavior.She has published many articles in national and international journals and is the author of chapters in books in the field of strategic management. She is sensitive to environmental and social issues and actively takes part in projects in this direction.

Mario Thomas Vassallo, PhD (Sheffield), MA (European Studies) (Melit.), BA (Honours) (Melit), is the Head of the Department of Public Policy, University of Malta. His research interests include multilevel governance, civil society, Europeanization, politics in arts and literature and evidence-based policy. He was invited to deliver international programs, including Tanzania (1997), Swaziland (2004), Corsica (2016) and Mauritius (2020). Between 2016 and 2020, he served as Rector's Delegate to the Institute for Public Services. He is the Co-editor of the book series Public Life in Malta, and his research works have been published by Palgrave Macmillan, Routledge, Emerald and other publishing houses. 
Serdar Yaman is currently working as an Assistant Professor at Sirnak University, Faculty of Economics and Administrative Sciences, Department of Business Administration. He received his bachelor's degree in Business Administration from Sirnak University in 2014. He received his master's and $\mathrm{PhD}$ degrees in Business Administration (Finance) from Mersin University in 2016 and 2020, respectively. He gives lectures in the field of finance and accounting since 2017. $\mathrm{He}$ does researches in financial management, corporate finance, portfolio management, behavioral finance, financial econometrics and financial modeling. He has participated in numerous international congress and symposiums. He has published papers in both national and international journals.

Münevvere Yıldız is an Assistant Professor at the Afyon Kocatepe University, Bolvadin School of Applied Sciences, Department of Banking and Insurence. She received her BSc and MSc degrees in the Department of Statistics at Ege University and at Afyon Kocatepe University, Turkey, respectively, in 2006 and 2009. She received her PhD in 2013 at the same department of Anadolu University, Eskisehir, Turkey. She has published papers and international and national conference papers in her research areas. Her research interests include statistical modeling, econometric methods, non-parametric regression and many other statistical technics.

Mag. Daniel Zdolšek is a Senior Lecturer of Accounting and Auditing at the University of Maribor, Slovenia, Faculty of Economics and Business. His research mostly focuses on the field of auditing, internal auditing, accounting, taxation and also interdisciplinary topics. Recently, he started to research sustainability issues in relation to non-financial reporting and standard setting. He has published in journals Economic Research-Ekonomska Istraživanja, Journal of East European Management Studies, Actual Problems of Economics, etc. He has professional experience and serves as a Member of the Experts Council at the Slovenian Institute of Auditors, Member of the Board at the Chapter of Forensic Accountants at the Association of Accountants, Treasurers and Auditors of Slovenia. Previously he was Member of the Internal Auditors Committee at the Slovenian Institute of Auditors. He cooperates with the Slovenian Institute of Auditors and trains prospective experts in the field on internal control and auditing. 
This page intentionally left blank 


\section{Foreword}

Is the world sleepwalking into a crisis? Global risks are intensifying but the collective will to tackle them and to collect on opportunities appears to be available but are we lacking in our response? The world may be moving into a new phase of state-centered politics as noted in the Global Risks Report (2019, 14th Edition - http://www3.weforum.org/docs/WEF_Global_Risks_Report_2019. pdf). The idea of "taking back control" - whether domestically from political rivals or externally from multilateral or supranational organizations - resonates across many countries and many issues. The energy now being expended on consolidating or recovering national control risks and weakening collective responses to emerging global challenges. We are drifting deeper into global problems from which we may struggle to extricate ourselves.

A new, highly complex and destabilized "domain of risk" is emerging. This includes the risk of a collapse in key social, environmental and economic systems, at local and potentially even global levels. This new risk domain affects virtually all areas of policy and politics, and it is doubtful that societies around the world are adequately prepared to manage this risk.

Financial structure decisions have evolved, from treating profitability as given, to acknowledging that human actions affect profitability, to recognizing that value depends on the allocation of decisions or control.

Therefore, as noted above the focus of this book series is on five areas of concern, highlighted in the Global Risks Perception Survey, which frame much of the analysis in subsequent chapters: (1) economic vulnerabilities; (2) geopolitical tensions; (3) societal and political strains; (4) environmental fragilities; and (5) technological instabilities. This in the end all lead to financial distress and in turn societal problems.

In this book series we argue that the decision or control approach is useful, even though it is at an early stage of development, and that the approach has some empirical content. It can throw light on the structure of capital contracts and the reasons for the diversity of objectives.

Hence, this Emerald book series: "Emerald studies in Finance Insurance and Risk Management Edition Volume 03" brings together in one volume 13 chapter/studies about Insurance and Risk Management responses to disruptions caused by social, economic and environmental challenges to try an stabilize the economy in an effort to ensure sustainability. 
Challenges destabilize the norm and create distresses and disruptions in, for example, the culture, the technology, regulations, the environmental, etc., that influence the pace of finance and economic activities since it requires a change to the norm.

Professor Simon Grima 